\title{
Nutritional Variation of Different Feed Ingredients and Compound Feed Found in Different Parts of Nepal
}

\author{
Megh R. Tiwari ${ }^{1}$, Shreekrishna Khanal ${ }^{2}$, Basanta Shrestha ${ }^{2}$ and Raj K. Jha ${ }^{2}$ \\ ${ }^{1}$ Regional Agricultural Research Station, Lumle, Kaski \\ ${ }^{2}$ Animal Nutrition Division, Kumaltar, Lalitpur
}

\begin{abstract}
Many feed industries in various parts of the country have been producing and marketing different types of compound feeds. The source of feed ingredients also varies greatly which will ultimately lead to the variation in the quality of finished products. Altogether 493 samples of 50 different feed ingredients and compound feed were collected from Baglung, Baitadi, Banke, Chitwan, Darchula, Dolakha, Dolpa, Gorkha, Ilam, Jhapa, Kathmandu, Kaski, Lalitpur, Lamjung, Morang, Mahottary, Makwanpur, Myagdi, Nawal Parasi, Parbat, Parsa, Rasuwa, Rupandehi, Sankhuwasava, Sunsari, Saptari, Sarlahi, Sindhupalchok, Siraha, Syangja and Tanahun districts. Highest content of dry matter $(99.51 \%)$, organic matter $(98.45 \%)$, total ash (98.14\%) and crude protein (67.85\%) was recorded for oyster cell, white maize grain, oyster cell and meat meal respectively. Similarly, the rice husk was found to be superior in crude fibre content $(34.46 \%)$ In terms of mineral oyster cell was found to be superior in calcium content (35.94\%) and bone meal in phosphorous content (1.59\%) as compared to other feed ingredients.
\end{abstract}

Key words: Crude fibre, crude protein, dry matter, feed ingredients, organic matter, total ash

\section{INTRODUCTION}

Many feed industries in various parts of the country have been producing and marketing different types of compound feeds. Feed supplements and other feed materials intended for feeding different species of livestock and poultry birds. The source of feed ingredients also varies greatly which will ultimately lead to the variation in the quality of finished products. Quality of these feed materials produced by various feed manufacturers should be required of standard before and after reaching to the farmers for a certain period of time so that farmers get their intended benefit from their animals by feeding these feeds or feed ingredients. Due to the lack of knowledge on nutritive value of feed and feed ingredients farmers are unable to formulate the balance diet for their animals. As a result quality status of these feed ingredients and their effect on animal performance is not known properly. Scientific study on the evaluation of the quality of such feeds and feed ingredients thus becomes necessary to satisfy the farmers, scientists and the feed manufacturers for various purposes. Determining the quality of these feed ingredients will help to address this problem.

Determining the quality of feed ingredients will help select feed industries the appropriate ingredients in maintaining the quality of their product. Both these information will also be useful for the researchers and scientists for preparing suitable feed formulae according to the demand of the farmers.

\section{Sample collection}

\section{METHODOLOGY}

A household survey with semi structured questionnaire was carried out in 31 districts of Nepal during past 12 years (1990-2001) by Animal Nutrition Division, Khumaltar, Lalitpur for identifying the different feed ingredients which farmers use to feed their animals. Samples of both feed ingredients and 
compound feed were taken from the farmer's households during survey period. As per expression of the farmers, generally they used compound feed manufactured by Cattle Feed Industry of Hetauda. The name and number of samples taken from the districts is given in Table 1.

Table 1. District-wise sample collection

\begin{tabular}{llrrlr}
\hline SN & District & Number of observation & SN & District & Number of observation \\
\hline 1 & Baglung & 3 & 17 & Makwanpur & 2 \\
2 & Baitadi & 2 & 18 & Myagdi & 7 \\
3 & Banke & 25 & 19 & Nawal Parasi & 13 \\
4 & Chitwan & 16 & 20 & Parbat & 3 \\
5 & Darchula & 4 & 21 & Parsa & 1 \\
6 & Dolakha & 7 & 22 & Rasuwa & 2 \\
7 & Dolpa & 8 & 23 & Rupendehi & 36 \\
8 & Gorakha & 1 & 24 & Sankhuwasava & 9 \\
9 & Illam & 7 & 25 & Sunsari & 12 \\
10 & Jhapa & 5 & 26 & Saptari & 74 \\
11 & Kathmandu & 21 & 27 & Sarlahi & 11 \\
12 & Kaski & 3 & 28 & Sindhupalchok & 5 \\
13 & Lalitpur & 19 & 29 & Siraha & 48 \\
14 & Lamjung & 13 & 30 & Syangja & 2 \\
15 & Morang & 29 & 31 & Tanahun & 2 \\
16 & Mahottary & 20 & & Total & 493 \\
\hline
\end{tabular}

\section{Chemical and data analysis}

The samples were dried to a constant weight under laboratory condition (Aman and Hesselmen 1984) and were grinded approximately 2-mm size as revealed by Wu et al (1994) and Luhaloo et al (1996). Sample were subjected to laboratory analysis for proximate components (AOAC 1980) and mineral (Ca and P). Calcium content was determined by titrimetric method and Phosphorous by photospectrometer. SPSS software was used to analyze data.

\section{RESULTS AND DISCUSSION}

\section{Proximate components}

Dry matter, organic matter, total ash, crude protein and crude fibre (proximate component) content of different feed ingredients and compound feed is given in Annex 1.

\section{Dry matter (DM)}

Annex 1 revealed that altogether 30 types of feed ingredients were evaluated for their dry matter content, however, 43 types were collected. Dry matter content of 14 feed ingredients was found in the range of $85-90 \%$ followed by $90-95$ and $80-85 \%$. There were only 2 feed ingredients that had dry matter content above $95 \%$, however it varied between 82.31 to $99.51 \%$. Highest dry matter content was recorded for oyster cell (99.51\%) followed by rice husk and bone meal (96.3 and $94.19 \%$ respectively). Similarly, the lowest amount of dry matter content was noted in millet grain $(82.31 \%)$. In case of compound feed, it was noted that feed for broiler 1,2 and 3 had dry matter content almost similar (92. $\%)$. Similarly, dry matter content of layer mash 1and 2 was found to be similar (87\%) whereas in the feed for layer mash 3 it was higher (90.27\%). Likewise, dry matter content of compound feed produced by Cattle Feed Industry, Hetauda for cattle was found to be $84.17 \%$. In general, dry matter content of different feed ingredients and compound feed was observed to be satisfactory. 


\section{Organic matter $(\mathbf{O M})$}

Organic matter content of most of the feed ingredient was recorded in the range of more than $95 \%$ followed by $90-95 \%$. There were 5 feed ingredients that organic matter content ranged from $85-90 \%$ whereas 5 feed ingredient had organic matter in its constituent below $85 \%$. The organic matter content of different feed ingredients varied between $1.86-98.45 \%$. Highest organic matter content was noted for white maize grain (98.45\%) followed by wheat flour and lentil grain (98.34 and 97.93\% respectively). Similarly, the least amount of organic matter was observed in oyster cell (1.86\%). In case of compound feed, broiler feed for 1,2 and 3 (starter, grower and finisher respectively) contained organic matter $86.88,87.26$ and $92 \%$ respectively. Similarly, organic matter content of layer mash 1 and 2 was recorded almost uniform ( 87.77 and $87.82 \%$ respectively) whereas in the feed of layer mash 3 it was $85.16 \%$. Compound feed for cattle of Cattle Feed Industry, Hetauda had organic matter content $90.80 \%$.

\section{Total ash (TA)}

Most of the feed ingredient contained total ash below 5\% followed by 5-10\% and $10-15 \%$. There were 5 feed ingredients which total ash content above $15 \%$. The total ash content of different feed ingredients was found to vary between 1.55 to $98.14 \%$. The highest total ash content was noted for oyster cell (98.14\%) followed by fish meal and bone meal (66.07 and 60.12\% respectively). Likewise, least amount of total ash was found in maize white grain $(1.55 \%)$. In case of compound feed, total ash content of layer mash 1 and 2 was similar (12.23 and 12.18\% respectively) whereas for layer mash 3 it was recorded $14.84 \%$. Similarly, total ash content of broiler 1, 2 and 3 was observed 13.12, 12.74 and $8 \%$ respectively. The compound feed for cattle prepared by Cattle Feed Industry, Hetauda had 9.2\% total ash in its constituent.

\section{Crude protein (CP)}

A total of 50 samples were evaluated for crude protein content. Among them, there were 12 samples in which protein content was recorded less than $10 \%$ in their constituent. There were 9 samples with crude protein content between $10-15 \%$. Similarly, there were 8 samples each that had crude protein content between 15-20, 20-25 and more than 30\% respectively. Likewise, there were only 5 samples of which crude protein content was recorded 25-30\%. Highest crude protein content was recorded for meat meal $(57.85 \%)$ followed by soybean cake and groundnut cake (45.07 and $41.61 \%$ respectively), however it varied from 2.44 to $67.85 \%$. The least amount of crude protein content was found in oyster cell $(2.44 \%)$. In case of compound feed made by Cattle Feed Hetauda, crude protein content of feed for broiler 3, 1 and layer mash 3 was noted almost similar (20.7, 20.22 and 20.06\% respectively). Similarly, in the feed of layer mash 2 and broiler 2 crude protein content was recorded 19.42 and 19.17 respectively. The crude protein content of feed for layer mash 3 and cattle was observed 17.91 and 16.58 respectively.

\section{Crude fibre (CF)}

Crude fibre content of 32 samples were evaluated from the collected 50 samples. Crude fibre content of 17 samples was found to be less than $10 \%$. There were 10 samples, which had crude fibre content in the range of 10-15\%. Similarly, there were few samples in which crude fibre content ranged between 15-20 and more than $20 \%$ respectively. Crude fibre content of different feed ingredients and compound feed was found to vary $2.4-34.46 \%$. The rice husk was found to be superior in crude fibre content $(34.46 \%)$ followed by pigeon pea, bran and husk ( 28.33 and $27.31 \%$ respectively). The least amount of crude fibre content was recorded for white maize flour (2.4\%). Analysis for crude fibre content of Cattle Feed Hetauda revealed that in the feed for broiler 3 had highest crude fibre in their constituent (10.65\%). The crude fibre content of feed for cattle, layer mash 1 and broiler 1 was noted similar $(8.66,8.6$ and 8.5\% respectively). Similarly, crude fibre in the feed for layer mash 2, broiler 2 and layer mash 3 was also found to be similar $(7.75,7.63$ and $7.05 \%$ respectively).

\section{Mineral content}

Mineral ( $\mathrm{Ca}$ and $\mathrm{P}$ ) content of feeds and feed ingredients is given in Annex 2 . 


\section{Calcium (Ca)}

Both calcium and phosphorous are important macro elements for animals. Altogether 44 samples were subjected for evaluation of calcium in its constituent. Most of the samples were rich in calcium content (more than $0.6 \%$ ) followed by $0.2-0.4$ and less than $0.2 \%$ respectively. There were only 8 samples which had calcium in the range of $0.4-0.6 \%$. Calcium content of different feed ingredients and feed was recorded in the range of $0.02-35.94 \%$. Highest amount of calcium was observed in the oyster cell (35.94\%) followed by bone meal and fish meal (22.03 and $3.42 \%$ respectively). Similarly, maize bran was found as a poor source of calcium $(0.02 \%)$ among the collected samples. In case of compound feed manufactured by Cattle Feed Plant of Hetauda, feed for broiler was not evaluated for their calcium content. But feed for layer mash 1, 2 and 3 was rich in calcium content $(1.17,1.83$ and $1.45 \%$ respectively) than that of feed for cattle $(0.46 \%)$.

\section{Phosphorous (P)}

Among the 44 samples only 42 samples were evaluated for their phosphorous content. Evaluation result showed that there were 15 feed samples, with phosphorous content ranging in between $0.2-0.4 \%$ followed by 14 and 10 samples in which phosphorous content was found in the range of more than $0.6 \%$ and in between $0.4-0.6 \%$ respectively. Phosphorous content of different feed ingredients and compound feed was noted in the range of $0.11-1.88 \%$. Highest amount of phosphorous was found in bone meal $(1.59 \%)$ followed by rice polish and sunflower cake in which phosphorous content was found to be 1.18 and $1.13 \%$ respectively whereas meat meal was recorded with least phosphorous $(0.11 \%)$. Similarly, feed for cattle and layer mash made by Hetauda Cattle Feed plant contained phosphorous in their constituent in 0.46 and $1.17 \%$ respectively.

\section{DISCUSSION}

In order to increase the livestock production and productivity, feed is the most important thing. Supplying adequate amount of feed for various livestock species involves the formulation of diet. Good quality feeds are produced from good quality feed ingredients. Feed ingredients are selected on the basis of their nutrient content as determined by chemical analysis. Oyster cells, was found to be superior in dry matter, total ash and calcium content $(99.51,98.14$ and $35.94 \%)$ respectively whereas it had least amount of crude protein and organic matter (2.44 and $1.86 \%$ respectively). Meat meal was recorded as good source of crude protein $(57.85 \%)$. In case of crude fibre, rice husk was better $(34.46 \%)$ than that of other feed ingredients. Similarly, white maize grain was found better for organic matter content (98.45\%). Likewise, bone meal is noted as good source of phosphorous (1.59\%). All these feed ingredients are easily available in the market and could be used by farmers to formulate the balance ration for their animals. Compound feed made by Cattle Feed Hetauda were found to be satisfactory in dry matter, organic matter, total ash and crude protein content, but it varied between batches. So, it was felt that there was necessity to check the quality of compound feed made by Cattle Feed Hetauda time to time.

Bista and Shrestha (2000) evaluated different feed ingredients from five development regions and reported that soybean found in eastern development region was significantly $(\mathrm{P}<0.05)$ rich in protein content $(40.3 \%)$ than that of central development region $(39.9 \%)$. Further, they noted that protein content $(12.65 \%)$ of maize of central development region was significantly higher $(\mathrm{P}<0.05)$ than that of other regions (average 6.5\%). Devkota et al (1995) analyzed nutrient content of feed mixtures prepared by different farmers and some fodder trees of Chitwan district and found that crude protein content of those feed mixtures was as low as $13.75 \%$ which was even lower than that of some fodder trees (Badahar, Kimbu, Dabdabe, Bakaino, Tanki and Dabdabe) found in Chitwan district. Further, they suggested for regular to evaluate the status and quality of concentrates or feeding mixture. 


\section{CONCLUSION}

The nutrient content of feed ingredients greatly depends upon the soil fertility, time of harvest, cultivation practices, application of fertilizer, frequency of irrigation, agroecological zones and etc. Therefore, it is concluded that, the knowledge of the nutrient content of the feed ingredients and compound feed available in Nepal would be useful to formulate ration that are cost efficient, sustainable and increase production performances of the animals.

\section{REFERENCES}

Aman P and K Hesselmen. 1984. Analysis of starch and other main constituents of cereal grains. Swedish J. Agric. Res.1:135-139.

AOAC. 1980. Official methods of analysis. $13^{\text {th }}$ Association of Analytical Chemists. Washington D.C.

Bista JD and RK Shrestha. 2000. Nutritional value and digestibility of fish feed stuffs of Nepal. In: Proceedings of the $4^{\text {th }}$ National Workshop on Livestock and Fisheries Research in Nepal, 24-26 April. ARS, Pakhribas, Dhankuta Nepal. Pp. 30-38.

Devkota NR, M Sapkota, JL Yadav, SS Pant and KR Pande. 1995. Indigenous management and nutrient analysis of fodder trees and feed mixtures in Chitwan. Institute of Agriculture and Animal Science Research Report, 1993-94 (FP Neopane, ed). Pp. 105-116.

Luhallo M, C Tilly and P Aman. 1996. Chemical Composition of air classified and stock sieved fractions of a high fibre rye milling steam. Swedish J. Agric. Res. 2:3-10.

Wu Y, AC Strigfellow and GC Inglett. 1994. Protein and $\alpha$ - glucan enriched fractions from high protein, high $\alpha-$ glucan barley's by sieving air classification. Cereal Chem. 71:220-223. 
Annex 1. Dry matter, organic matter, total ash, crude protein and crude fibre content of feed ingredients and compound feed

\begin{tabular}{|c|c|c|c|c|c|c|c|c|}
\hline $\mathrm{SN}$ & Name & Scientific name & $\begin{array}{r}\text { Dry } \\
\text { matter }\end{array}$ & $\begin{array}{r}\text { Organic } \\
\text { matter }\end{array}$ & $\begin{array}{r}\text { Total } \\
\text { ash }\end{array}$ & $\begin{array}{l}\text { Crude } \\
\text { protein }\end{array}$ & $\begin{array}{r}\text { Crude } \\
\text { fibre }\end{array}$ & $\begin{array}{r}\text { No of } \\
\text { samples }\end{array}$ \\
\hline & Feed ingredients & & & & & & & \\
\hline 1 & Bakula bran & Vicia fava & - & 75.32 & 24.68 & 16.42 & NA & 1 \\
\hline 2 & Blackgram & Vigna mungo & 90.01 & 95.80 & 4.20 & 25.25 & 6.17 & 6 \\
\hline 3 & Blackgram bran & Vigna mungo & 89.20 & 92.40 & 7.60 & 16.35 & NA & 2 \\
\hline 4 & Bone meal & - & 94.19 & 39.11 & 60.12 & 30.41 & NA & 3 \\
\hline 5 & Buckwheat & Fagopyrum tataricum & 86.77 & 92.72 & 7.28 & 9.31 & 15.25 & 5 \\
\hline 6 & Chick pea & Cicer arietinum & 91.0 & 95.98 & 4.02 & 17.48 & 12.56 & 5 \\
\hline 7 & Cowpea & Vigna stnensis & 89.0 & 95.11 & 4.89 & 26.50 & 8.01 & 9 \\
\hline 8 & Fishmeal & - & 91.20 & 33.93 & 66.07 & 30.55 & 2.96 & 6 \\
\hline 9 & Horse gram & Dolichos sps. & 82.80 & 95.35 & 4.65 & 25.0 & 7.90 & 2 \\
\hline 10 & Groundnut cake & Arachis hypogaea & - & 93.61 & 6.39 & 41.61 & NA & 12 \\
\hline 11 & Lentil & Lens culinaris & - & 97.93 & 2.07 & 10.28 & NA & 1 \\
\hline 12 & Lentil bran & Lens culinaris Medic & - & 90.58 & 9.42 & 13.27 & 10.40 & 10 \\
\hline 13 & Lentil husk & Lens culinaris & - & 89.07 & 10.93 & 9.71 & NA & 1 \\
\hline 14 & Maize flour, white & Zea mays & 84.50 & 96.36 & 2.64 & 9.18 & 2.40 & 14 \\
\hline 15 & Maize flour, yellow & Zea mays & 87.39 & 96.82 & 3.08 & 9.77 & 3.03 & 8 \\
\hline 16 & Maize, red & Zea mays & 89.34 & 97.14 & 2.86 & 9.96 & 4.24 & 19 \\
\hline 17 & Maize, white & Zea mays & 88.98 & 98.45 & 1.55 & 10.97 & 3.02 & 13 \\
\hline 18 & Maize, yellow & Zea mays & - & 96.09 & 3.91 & 9.16 & NA & 3 \\
\hline 19 & Maize bran & Zea mays & 84.50 & 94.61 & 5.39 & 8.26 & 16.90 & 2 \\
\hline 20 & Masyang & Vigna umbellata & 85.27 & 96.40 & 3.60 & 23.36 & 7.36 & 3 \\
\hline 21 & Meat meal & - & 88.89 & 81.86 & 18.14 & 57.85 & NA & 1 \\
\hline 22 & Millet & Eleusine coracana & 82.31 & 96.71 & 3.29 & 7.65 & 8.64 & 9 \\
\hline 23 & Millet bran & Eleusine coracana & 89.20 & 92.40 & 7.60 & 16.35 & NA & 1 \\
\hline 24 & Mung bran & Vigna radiata & 90.66 & 94.50 & 5.50 & 21.50 & NA & 3 \\
\hline 25 & Mustard cake & Brassica campestris & 91.88 & 91.28 & 8.72 & 27.48 & 11.60 & 34 \\
\hline 26 & Oat & Avena sativa & 93.11 & 93.25 & 6.75 & 11.40 & NA & 2 \\
\hline 27 & Oyster shell & - & 99.51 & 1.86 & 98.14 & 2.44 & NA & 1 \\
\hline 28 & Pegeon pea & Cajanus cajan & 87.25 & 95.48 & 4.52 & 23.18 & 10.82 & 5 \\
\hline 29 & Pegeon pea bran & Cajanus cajan & 86.96 & 95.46 & 4.54 & 13.20 & 28.33 & 3 \\
\hline 30 & Pegeon pea husk & Cajanus cajan & - & 96.20 & 3.80 & 13.32 & 27.31 & 2 \\
\hline 31 & Rice bran & Oriza sativa & 83.69 & 86.42 & 13.38 & 9.52 & 12.61 & 77 \\
\hline 32 & Rice husk & Oriza sativa & 96.30 & 85.19 & 14.81 & 6.60 & 34.46 & 3 \\
\hline 33 & Rice polish & Oriza sativa & - & 89.81 & 10.19 & 12.77 & 11.64 & 2 \\
\hline 34 & Sesame cake & Minum usitatissimum & 90.21 & 93.57 & 6.43 & 24.51 & 11.30 & 4 \\
\hline 35 & Soybean & Glycine $\max$ & 86.74 & 92.99 & 7.01 & 32.0 & NA & 15 \\
\hline 36 & Soybean cake & Glycine $\max$ & 92.04 & 92.34 & 7.64 & 45.07 & NA & 34 \\
\hline 37 & Sunflower & Helianthus annus & - & 91.63 & 8.37 & 30.03 & NA & 1 \\
\hline 38 & Sunflower cake & Helianthus annus & - & 90.99 & 9.01 & 37.29 & NA & 1 \\
\hline 39 & Til cake & Daesamum indicum & - & 88.98 & 11.02 & 28.26 & 12.07 & 3 \\
\hline 40 & Wheat & Triticum astivum & 86.70 & 96.24 & 3.76 & 14.57 & 2.95 & 3 \\
\hline 41 & Wheat bran & Triticum astivum & 86.75 & 93.59 & 6.41 & 12.65 & 11.64 & 36 \\
\hline 42 & $\begin{array}{l}\text { Wheat flour } \\
\text { Compound feed }\end{array}$ & Triticum astivum & - & 98.34 & 1.66 & 8.40 & NA & 1 \\
\hline 1 & Broiler 1 & - & 92.37 & 86.88 & 13.12 & 20.22 & 8.50 & 9 \\
\hline 2 & Broiler 2 & - & 92.18 & 87.26 & 12.74 & 19.17 & 7.63 & 9 \\
\hline 3 & Broiler 3 & - & 92.90 & 92.0 & 8.0 & 20.70 & 10.65 & 2 \\
\hline 4 & Cattle feed & - & 84.17 & 90.80 & 9.20 & 16.58 & 8.66 & 75 \\
\hline 5 & Layer mash 1 & - & 87.87 & 87.77 & 12.23 & 20.06 & 8.60 & 22 \\
\hline 6 & Layer mash 2 & - & 87.74 & 87.82 & 12.18 & 19.42 & 7.75 & 17 \\
\hline 7 & Layer mash 3 & - & 90.27 & 85.16 & 14.84 & 17.91 & 7.05 & 15 \\
\hline
\end{tabular}


Annex 2. Mineral content of feed ingredients and compound feed

\begin{tabular}{|c|c|c|c|c|}
\hline \multirow[t]{2}{*}{ SN } & \multirow[t]{2}{*}{ Name } & \multirow[t]{2}{*}{ Scientific name } & \multicolumn{2}{|r|}{ Mineral, \% } \\
\hline & & & Calcium & Phosphorous \\
\hline \multicolumn{5}{|c|}{ Feed ingredient } \\
\hline 1 & Bakula bran & Vicia faba & 1.12 & 0.29 \\
\hline 2 & Blackgram & Vigna mungo & 0.13 & 0.43 \\
\hline 3 & Blackgram bran & Vigna mungo & 0.56 & 0.38 \\
\hline 4 & Bone meal & - & 22.03 & 1.59 \\
\hline 5 & Buckwheat & Fagopyrum tataicum & 1.15 & 0.28 \\
\hline 6 & Chick pea & Cicer arietinum & 0.23 & 0.19 \\
\hline 7 & Cowpea & Vigna sinensis & 0.22 & 0.44 \\
\hline 8 & Fishmeal & - & 3.42 & 0.94 \\
\hline 9 & Horse gram & Dolichos sps & 0.29 & 0.39 \\
\hline 10 & Groundnut cake & Arachis hypogaea & 0.30 & 1.04 \\
\hline 11 & Lentil & Lens culinaris & 0.42 & 0.58 \\
\hline 12 & Lentil bran & Lens culinaris & 0.58 & 0.31 \\
\hline 13 & Lentil husk & Lens culinaris & 1.23 & 0.18 \\
\hline 14 & Maize flour, white & Zea mays & 0.11 & 0.35 \\
\hline 15 & Maize flour, yellow & Zea mays & 0.15 & 0.45 \\
\hline 16 & Maize, red & Zea mays & 0.15 & 0.39 \\
\hline 17 & Maize, white & Zea mays & 0.10 & 0.34 \\
\hline 18 & Maize, yellow & Zea mays & 1.80 & 0.69 \\
\hline 19 & Maize bran & Zea mays & 0.02 & 0.20 \\
\hline 20 & Masyang & Vigna unbellanta & 0.26 & 0.42 \\
\hline 21 & Meat meal & - & 1.64 & 0.11 \\
\hline 22 & Millet & Eleusine coracana & 0.30 & 0.31 \\
\hline 23 & Millet bran & Eleusine coracana & 0.64 & 0.30 \\
\hline 24 & Mung bran & Vigna radiata & 0.38 & 0.37 \\
\hline 25 & Mustard cake & Brassica campestris & 1.25 & 0.97 \\
\hline 26 & Oat grain & Avena sativa & 0.25 & 0.48 \\
\hline 27 & Oyster meal & - & 35.94 & 0.80 \\
\hline 28 & Pigeon pea & Cajanus cajan & 0.24 & 0.35 \\
\hline 29 & Pigeon pea bran & Cajanus cajan & 0.43 & 0.21 \\
\hline 30 & Rice bran & Oriza sativa & 0.32 & 0.66 \\
\hline 31 & Rice husk & Oriza sativa & 0.11 & 0.73 \\
\hline 32 & Rice polish & Oriza sativa & 0.14 & 1.18 \\
\hline 33 & Soybean & Glycine $\max$ & 0.43 & 0.59 \\
\hline 34 & Soybean cake & Glycine $\max$ & 1.61 & 0.67 \\
\hline 35 & Sunflower & Helianthus annus & 0.60 & 1.13 \\
\hline 36 & Sunflower cake & Helianthus annus & 0.64 & 0.98 \\
\hline 37 & Wheat & Triticum astivum & 0.12 & 0.52 \\
\hline 38 & Wheat bran & Triticum astivum & 0.55 & 0.55 \\
\hline 39 & Wheat flour & Triticum astivum & 0.64 & 0.30 \\
\hline \multicolumn{5}{|c|}{ Compound feed } \\
\hline 1 & Cattle feed & - & 0.46 & 0.82 \\
\hline 2 & Layer mash 1 & - & 1.17 & 0.54 \\
\hline 3 & Layer mash 2 & - & 1.83 & \\
\hline 4 & Layer mash 3 & - & 1.45 & \\
\hline
\end{tabular}

